\title{
Trade in Information Technology and Wage Inequality in the Digital Economy: The Case of Korea
}

\author{
SANG-CHUL YOON ${ }^{*}$
}

This paper examines the impact of trade in information technology (IT) on wage inequality in the digital economy. The empirical results based on the quarterly data for the period 1994-2004 in Korea show the evidence supportive of the view that trade in IT as intermediate inputs has escalated wage inequality in digital economy, which supports the Feenstra-Hanson (2001) hypothesis.

Keywords: Trade in IT, Wage Inequality, Digital Economy, Korea 


\section{INTRODUCTION}

I

n digital economy, information technology (IT) serves as the key driving force for economic change, restructuring of businesses, influencing skills and employment, and economic growth (OECD, 2004). ${ }^{1}$ The pervasive use of IT as intermediate inputs can thus play in increasing wage inequality as well as creating new economic efficiency in the digital economy. ${ }^{2}$ Although trade in IT as intermediate inputs has increased sharply over the past decade, rigorous empirical research about the impact of trade in IT on wage inequality has been actively explored, unlike research on the impact of IT on income distribution. Given that Korea is an eminent international IT center, both analysts and policy-makers should pay more attention to what extent the widening wage inequality is associated with the increased trade in IT.

The Korean economy has experienced increasing wage inequality since the mid-1990s. Over the same period, there have been dramatic increases in trade in IT as intermediate inputs. ${ }^{3}$ The recent rise of wage inequality, which largely parallels the increasing share of IT in trade, suggests that trade in IT is producing positive and probably lasting changes in the relative wage of IT-intensive to less IT-intensive industries in Korea. This paper empirically studies the link between trade in IT and wage inequality in the digital economy. Specifically, the current paper deals with the case of Korea with respect to the impact of trade in IT on wage inequality, using quarterly time series data for the period 1994-2004.

\section{THE IMPACT OF TRADE ON WAGE INEQUALITY}

Many factors such as technological change, trade values, FDI flows, and per capita income level influence the rise and fall of wage disparity. Of these factors, the relationship between per capita income and inequality has been a popular topic of economic research. Kuznets (1955) hypothesizes that there is an inverted U-shaped relationship between growth and inequality. The results of the previous studies suggest that there is no general tendency for inequality to move to any particular direction with economic growth (Barro, 2000; Chang and Ram, 2000; Lopez, 2006).

The impact of trade on wage inequality has a popular subject of research and debate in the past decades. Stolper and Samuelson (1941) argue that owners of the abundant factor benefit from free trade, whereas owners of the scarce factor suffer. It implies that greater openness reduces overall wage inequality in developing countries, but increases overall wage inequality in developed countries. Nowadays, the idea that trade in intermediate inputs can have an impact on wage inequality is gaining widespread acceptance among trade econo- 
mists (Feenstra and Hanson, 2001; Ho, Wei and Wong, 2005). Feenstra and Hanson (2001) argue that trade in intermediate inputs, or global production sharing is a potentially important explanation for the increase in the wage gap between skilled and unskilled workers in the U.S. and elsewhere. They show empirically that trade in intermediate inputs has much the same impact on labor demand as does skill-biased technical change: both of these will shift demand away from low-skilled activities, while raising relative demand and wages of the higher skilled ones. Using the quarterly time series data for the period of 1991-2002 and the cointegration analysis, Ho, Wei and Wong (2005) find a long run causal relationship between outsourcing or outward processing trade with Mainland China and the wage inequality in Hong Kong.

\section{THE EMPIRICAL EVIDENCES}

In order to investigate the impact of trade in IT as intermediate inputs on wage inequality in Korea, the following regression model is employed.

$$
W I_{i t}=\beta_{0}+\beta_{1}(P G D P)_{i t}+\beta_{2}(P G D P)_{i t}^{2}+\beta_{3}(I T)_{i t}+\beta_{4}(N O N I T)_{i t}+\delta D U M+\varepsilon_{i t}
$$

In the above equation, $W I$ is defined as (the wage of workers in the IT-intensive industries/that in less IT-intensive industries worker). ${ }^{4} P G D P$ is defined as per capita GDP expressed in terms of US\$ thousands. 5 IT and NONIT are defined as (IT export+IT import)/GDP and (non-IT export+non-IT import)/GDP, respectively. ${ }^{6}$ DUM is defined as an intercept dummy variable. Trade in IT intermediates to GDP ratio in Korea has sharply declined with the IT recession in the U.S. and Korea. This structural change could be a set of structural economic conditions in this analysis. Thus we may create a dummy variable as stated in the following:

$$
D U M= \begin{cases}0 & 1994 Q 1-2001 Q 1 \\ 1 & 2001 Q 2-2004 Q 4\end{cases}
$$

$\mathcal{E}$ is the conventionally assumed disturbance term. All variables such as the WI, PGDP, IT and NONIT are seasonally adjusted.

According to the Kuznets's inverted U-shaped relationship between inequality and per capita GDP, $\beta_{1}, \beta_{2}$ are expected to be positive and negative respectively. The impact of trade in IT as intermediate inputs on wage inequality, $\beta_{3}$ would be expected to be positive if the Feenstra-Hanson hypothesis is valid, considering that IT provides vital inputs in the production of other goods and services 
in the digital economy. There are competing views on the signs of $\beta_{4}$. The effects of trade in non-IT on wage inequality, $\beta_{4}$ would be expected to be negative according to the Stolper-Samuelson theorem, assuming that Korea was a labor abundant country. However, $\beta_{4}$ would be expected to be positive if the Stolper-Samuelson theorem is valid, assuming that Korea is a capital abundant country.

In this paper we analyze the regression results based on the intuition provided by eq. (1). Regression analysis applied to the equation using non-stationary variables may lead to spurious regression. Therefore, it is necessary to examine the stationarity of the variables concerned. To check the stationarity of the variables concerned, we have applied the augmented Dickey-Fuller test and Phillips-Perron test. As shown in Table 1, these unit root test results show that the level of all variables concerned are not stationary at the $5 \%$ level of significance. Therefore, we also examine whether the first differenced forms of the variables are stationary or not. The differenced forms of most of the variables are shown to be stationary at the $5 \%$ level of significance. Therefore, all the variables are assumed to be integrated of order one.

Table 1. Unit Root Test Results for the Variables Concerned: Augmented Dickey-fuller (Adf) AND Phillips and Perron (PP) Tests

\begin{tabular}{lccl}
\hline \multicolumn{1}{c}{ Variables } & & ADF test & PP test \\
\hline \multirow{2}{*}{ WI } & level & 0.511 & -0.215 \\
& $\Delta$ & $-6.415^{* *}$ & $-9.335^{* *}$ \\
PGDP & level & -1.933 & -1.763 \\
& $\Delta$ & $-4.081^{* *}$ & $-5.085^{* *}$ \\
PGDP ${ }^{2}$ & level & -1.10 & -1.187 \\
& $\Delta$ & $-3.844^{* *}$ & $-6.258^{* *}$ \\
IT & level & -1.326 & -1.474 \\
& $\Delta$ & $-3.359^{* *}$ & $-6.174^{* *}$ \\
NONIT & level & -1.933 & -2.247 \\
& $\Delta$ & $-4.642^{* *}$ & $-8.066^{* *}$ \\
DUM & level & -0.662 & -0.686 \\
& $\Delta$ & $-3.651^{* *}$ & $-6.482^{* *}$ \\
\hline
\end{tabular}

NOTES: For the ADF test, optimal lags are chosen by AR processes. When applying the PP test, Newey and West's (1987) suggestions are followed in choosing lags. The symbol $\Delta$ represents the results for the first-differenced forms of the variables. ${ }^{*}(* *)$ Statistically significant at $5(1) \%$ level of significance.

This analysis employs Johansen's (1988) method to reveal the cointegration relationship and to provide the cointegrating vectors.

Table 2 demonstrates that there exists at least a cointegrating vector among 
the $W I, P G D P,(P G D P)^{2}, I T, N O N I T$, and DUM at the $1 \%$ level of significance. The estimated signs of the coefficients are consistent with the expectation based on the Kuznets hypothesis. That is, we can say that there is weak evidence in the Kuznets hypothesis. The result also shows that when trade in non-IT increases, the relative wage of IT-intensive industries tends to decrease, which support the Stolper-Samuelson theorem, considering that Korea is a relatively labor abundant country compared with the major trade partners such as the U.S. and Japan. The coefficient for trade in IT shows that when trade in IT increases, the relative wage of IT-intensive industries tends to increase, which support the Feenstra-Hanson (2001) hypothesis. Overall, one can say that there is strong evidence supporting the view that trade in IT has deteriorated the situation of wage inequality in digital economy in the case of Korea.

\section{TABle 2. Johansen's CoIntegration Test}

\begin{tabular}{|c|c|c|c|c|c|c|c|c|c|}
\hline \multirow{2}{*}{$\begin{array}{c}\text { Null } \\
\text { hypothesis: } \\
\text { Cointegration } \\
\text { Vectors }\end{array}$} & \multirow{2}{*}{$\begin{array}{c}\text { Likelihood } \\
\text { Ratio } \\
\text { Statistics }\end{array}$} & \multicolumn{8}{|c|}{ Estimated Cointegrating Vectors } \\
\hline & & WI & PGDP & $(P G D P)^{2}$ & IT & non-IT & DUM & Constant & $\begin{array}{c}\text { Log } \\
\text { Likelihood }\end{array}$ \\
\hline $\begin{array}{l}\gamma=0 \\
\gamma \leq 1\end{array}$ & $\begin{array}{l}156.908^{* *} \\
94.354^{* *}\end{array}$ & 1.0 & $\begin{array}{l}-0.147 \\
(0.035)\end{array}$ & $\begin{array}{c}0.029 \\
(0.008)\end{array}$ & $\begin{array}{c}-0.804 \\
(0.074)\end{array}$ & $\begin{array}{c}0.369 \\
(0.083)\end{array}$ & $\begin{array}{l}-0.137 \\
(0.015)\end{array}$ & -0.965 & 423.278 \\
\hline $\begin{aligned} \gamma & =0 \\
\gamma & \leq 1\end{aligned}$ & $\begin{array}{l}89.289^{\circ "} \\
53.554^{\circ}\end{array}$ & 1.0 & $\begin{array}{c}-0.018 \\
(0.003)\end{array}$ & & $\begin{array}{l}-0.766 \\
(0.045)\end{array}$ & $\begin{array}{c}0.193 \\
(0.045)\end{array}$ & $\begin{array}{l}-0.089 \\
(0.002)\end{array}$ & -1.034 & 423.793 \\
\hline
\end{tabular}

NOTE: **(*) denotes statistical significance at $1 \%(5 \%)$ level.

Values vithin the parentheses under the calculated cointegrating vectors denote the standard errors.

\section{CONCLUDING REMARKS}

Using quarterly time series data for the period 1994-2004, this paper examines the impact of trade in IT and trade in non-IT as well as per capita GDP on the relative wage of IT-intensive to less IT-intensive industries in Korea. The empirical evidence shows that the variables concerned can, in general, be assumed to be integrated of order one. Johansen-Juselius cointegration test shows that the predictions of the Kuznets hypothesis as well as the Stolper-Samuelson hypothesis are supported in the case of Korea. In particular, trade in IT as intermediate inputs tends to escalate wage inequality in Korea, which supports the Feenstra-Hanson (2001) hypothesis. This wage inequality result suggests that better education and training for unskilled workers rather than the higher barriers for trade in IT can be an alternative public policy to narrow the gap between skills. 


\section{REFERENCE}

Barro, R. J. 2000. Inequality and growth in a panel of countries. Journal of Economic Growth 5: 5-32.

Brynjolfsson, E. and B. Kahin, ed. 2000. Understanding the Digital Economy: Data. Tools, and Research. Cambridge: The MIT Press.

Chang, J. Y. and R. Ram. 2000. Level of development, rate of economic growth, and income inequality. Economic Development and Cultural Change 48: 787-799.

Feenstra, R. C. and G. H. Hanson. 2001. Global Production Sharing and Rising Inequality: A Survey of Trade and Wages. NBER Working Paper No. 8372.

Ho, L. S., X. Wei, and W. C. Wong. 2005. The effect of outward processing trade on wage inequality: the Hong Kong case. Journal of International Economics 67: 241-257.

Johansen, S. 1988. Statistical analysis of cointegration vectors. Journal of Economic Dynamics and Control 12: 231-254.

Korea Information Strategy Development Institute. 2004. Digital Economy in Korea. Korea Information Strategy Development Institute.

Kuznets, S. 1955. Economic growth and income inequality. American Economic Review 45: 1-28.

Lopez, H. 2006. Growth and inequality: are the 1990s different? Economics Letters 93: $18-25$.

Newey, W. K. and K. D. West. 1987. A simple positive semi-definite heteroskedasticity and autocorrelation-consistent covariance matrix. Econometrica 55: 703-708.

OECD. 2004. OECD Information Technology Outlook. Paris: OECD.

Stolper, W. and P. Samuelson. 1941. Protection and real wages. Review of Economic Studies 9: 58-73.

U.S. Department of Commerce. 2003. Digital Economy 2003. Economics and Statistics Administration, U.S. Department of Commerce, Washington, D.C. 


\section{Appendix}

CLASSIFICATION OF INDIVIDUAL INDUSTRY BY IT INTENSITY

The more IT-intensive industries

$\begin{array}{ll}10 / 11 / 12 / 16 & 15 / 17 / 18 / 19 \\ 22 / 23 / 24 / 29 & 20 / 21 / 25 / 26 / 27 / 28 \\ 30 / 31 / 32 / 35 & 33 / 34 / 36 / 37 \\ 40 / 41 & 45 / 46 \\ 51 & 50 / 52 / 55 \\ 60 / 62 / 64 / 65 / 66 / 67 & 61 / 63 \\ 72 / 73 / 74 / 75 & 70 / 71 / 76 \\ 87 / 88 & 80 / 85 / 86 \\ 90 & 91 / 92 / 93\end{array}$

NOTE: IT intensity within a 2-digit industry varies a great deal. However, we had to apply our IT intensity criterion at the 2-digit Korean Standard Industrial Classification (KSIC) level. SOURCES: U.S. Department of Commerce, 2003.

Korea Information Strategy Development Institute, 2004. 


\section{ENDNOTES}

1 As in Brynjolfsson and Kahin (2000), the term "digital economy" refers specifically to the recent and still largely unrealized transformation of all sectors of the economy by the computer-enabled digitization of information, and the digital economy includes goods or services whose development, production, sale, or provision is critically dependent upon digital technologies.

2 For example, average growth for IT-intensive industries in the U.S. economy between 1989 and 2001 was over 3 percent, far exceeding growth in the less IT-intensive industries which averaged 0.42 percent (U.S. Department of Commerce, 2003).

${ }^{3}$ The Gini coefficients for wage income in Korea climbed continuously from 0.272 in 1994 to 0.314 in 2004. Over the same period, trade in IT to GDP ratio rose sharply from 0.085 to 0.189 .

4 In this paper, we grouped the industries into two groups, either IT-intensive or less IT-intensive (see Appendix). This grouping enables us to compare the wage of the IT-intensive to less IT-intensive industries.Data for wage are taken from the Ministry of Labor, Labor Statistics of Korea, various issues.

s Data for per capita GDP are taken from the Korea Trade Association, Trade Statistics of Korea, various issues.

${ }^{6}$ In this paper, we define IT as intermediate inputs as Ministry of Trade and Industry (MTI) \# $811,812,813,821,831,832,833,834,836$, and 850 . Data for trade are taken from the Korea Trade Association, Trade Statistics of Korea, various issues. 